\title{
Regional pulmonary ventilation and perfusion distribution in patients with untreated idiopathic scoliosis
}

\author{
B. BAKE, J. B JURE ${ }^{1}$, J.KASALICHÝ ${ }^{2}$, and A. NACHEMSON \\ Departments of Clinical Physiology and Orthopaedic Surgery, University of Göteborg, Göteborg, Sweden
}

Regional lung function using xenon-133 was studied in 45 seated patients aged 11 to 78 years with untreated idiopathic scoliosis and angulation of curvature between 10 and $190^{\circ}$. Perfusion distribution was assessed by intravenous bolus injection of ${ }^{133} \mathrm{Xe}$ and distribution of ventilation to volume ratios by washouts after inhalation and intravenous injection.

No consistent differences between the lungs on the convex and concave sides of the curvature were found. The lung bases were found to be more severely affected than the apices, perfusion and ventilation being progressively reduced with increasing deformity. There was evidence of inhomogeneity within regions and it is suggested that in younger patients the ventilation and perfusion within regions are better matched than in older patients.

The deformity of the thoracic cage in patients with scoliosis has a serious effect on the lungs such as inadequate alveolar ventilation, ventilation/perfusion disturbances (Shaw and Read, 1960), and vascular bed restriction (Naeye, 1961). The end result is hypercapnia, hypoxia, pulmonary arterial hypertension, and cor pulmonale (Hanley, Platts, Clifton, and Morris, 1958; Bergofsky, Turino, and Fishman, 1959; Bruderman and Stein, 1961 ; Fishman, 1965). On histological examination of the lungs, some regions show alveolar dilatation and others partial collapse (Bergofsky et al., 1959; Reid, 1969). The lung volumes and maximum voluntary ventilation are reduced (Hanley et al., 1958; Bruderman and Stein, 1961 ; Prime, 1965) in proportion to the degree of spinal angulation (Makley et al., 1968 ; Bjure et al., 1970).

As is apparent from previous reports, disturbances of regional ventilation and perfusion might be predicted from the changes in overall lung function. Dollery, Gillam, Hugh-Jones, and Zorab (1965), using ${ }^{133} \mathrm{Xe}$ technique, showed in the 10 patients investigated an abnormally even perfusion distribution and a reduced basal ventilation in at least three of them. However, these three patients also had mild chronic bronchitis and the authors were not able to attribute the basal hypoventila-

1Reprint requests to: Jan Bjure, Department of Clinical Physiology, Children's Hospital, 41346 Göteborg, Sweden

2Present address: Research Institute of the Medical Use of Radioisotopes, Budejovická 800, Praha-krc, Czechoslovakia tion to the deformity. Low perfusion in the basal zones of the lungs in the sitting position was also observed and confirmed by Shannon, Riseborough, Valenca, and Kazemi (1970). In our previous paper (Bjure et al., 1970) we showed that in some of these patients airway closure occurred at an earlier age than predicted and that the volume at which the airways started to close was correlated with the angle of the curvature and the age of the patient.

The purpose of this paper is to study in more detail the influence of varying severity of spinal deformity on the distribution of ventilation and blood flow in the lungs of patients with untreated idiopathic scoliosis. Data for younger (below the age of 40 years) and older (above the age of 40 years) patients are compared in an attempt to analyse the effect of age on the distribution of ventilation and blood flow.

\section{MATERIAL}

The original material consisted of 50 patients with untreated idiopathic scoliosis and has recently been described in more detail (Bjure et al., 1970).

From this material 45 patients are included in the present investigation. None of the patients had a history of chronic bronchitis nor did dynamic spirometry reveal any airway obstruction in any of the 45 patients studied. For various reasons three of these patients could not take part in all stages of the procedure. Table I summarizes some clinical and spiro- 
T A B LE I

CLINICAL DATA

\begin{tabular}{|c|c|c|c|c|c|c|c|c|c|c|c|c|}
\hline \multicolumn{2}{|c|}{ Subdivisions according to: } & \multirow{2}{*}{$\begin{array}{c}\text { Number } \\
\text { of } \\
\text { Patients }\end{array}$} & \multirow{2}{*}{$\begin{array}{c}\text { Mean } \\
\text { Age } \\
\text { (yr) }\end{array}$} & \multirow{2}{*}{$\begin{array}{c}\text { Mean } \\
\text { Angle } \\
\text { (degrees) }\end{array}$} & \multirow{2}{*}{$\begin{array}{c}\text { TLC } \\
\text { (\% pred.) }\end{array}$} & \multirow{2}{*}{$\begin{array}{c}\text { VC } \\
(\% \text { pred. })\end{array}$} & \multirow{2}{*}{$\begin{array}{c}\text { FRC } \\
(\% \text { pred.) }\end{array}$} & \multicolumn{5}{|c|}{$\begin{array}{c}\text { Number of Patients according } \\
\text { to Degree of Dyspnoea }\end{array}$} \\
\hline Angle of Scoliosis & Age (yr) & & & & & & & I & II & III & IV & V \\
\hline$<60^{\circ}$ & $\begin{array}{l}<40 \\
\geqslant 40\end{array}$ & $\begin{array}{r}9 \\
12\end{array}$ & $\begin{array}{l}14 \\
56\end{array}$ & $\begin{array}{l}44 \\
30\end{array}$ & $\begin{array}{l}82 \\
87\end{array}$ & $\begin{array}{l}83 \\
82\end{array}$ & $\begin{array}{l}78 \\
88\end{array}$ & $\begin{array}{l}8 \\
7\end{array}$ & $\begin{array}{l}1 \\
5\end{array}$ & & & \\
\hline $60-99^{\circ}$ & $\begin{array}{l}<40 \\
\geqslant 40\end{array}$ & $\begin{array}{l}5 \\
5\end{array}$ & $\begin{array}{l}24 \\
54\end{array}$ & $\begin{array}{l}84 \\
74\end{array}$ & $\begin{array}{l}58 \\
78\end{array}$ & $\begin{array}{l}56 \\
71\end{array}$ & $\begin{array}{l}52 \\
70\end{array}$ & $\begin{array}{l}2 \\
2\end{array}$ & $\begin{array}{l}1 \\
1\end{array}$ & 2 & 2 & \\
\hline$\geq 100^{\circ}$ & $\begin{array}{l}<40 \\
\geqslant 40\end{array}$ & $\begin{array}{l}8 \\
6\end{array}$ & $\begin{array}{l}27 \\
52\end{array}$ & $\begin{array}{l}126 \\
123\end{array}$ & $\begin{array}{l}48 \\
52\end{array}$ & $\begin{array}{l}47 \\
47\end{array}$ & $\begin{array}{l}43 \\
50\end{array}$ & $\begin{array}{l}2 \\
1\end{array}$ & & $\begin{array}{l}4 \\
3\end{array}$ & 2 & 2 \\
\hline
\end{tabular}

TLC $=$ total lung capacity; $V C=$ vital capacity; $F R C=$ functional residual capacity.

For predicting normal values a corrected height was used (Bjure, Grimby, and Nachemson, 1968). In that paper the regression equation -1 for the relation between the loss of trunk height $(y)$ and the angulation of the curvature $(x)$ was given an erroneous sign. The correct equation $\bigcirc$ is $\log y=0.011 x-0.177(r=0.94)$.

The degree of dyspnoea was evaluated according to the questionnaire approved by the College of General Practitioners (1961):

I No complaints;

II Dyspnoea on walking fast or up a small hill;

III Dyspnoea on accompanied walking at normal speed on level ground;

IV Need to stop due to dyspnoea on walking alone on level giound;

V Dyspnoea from dressing or similar activities.

metric data and gives the different subdivisions according to the angle of scoliosis and the age of the patients. Their ages ranged between 11 and 78 years and the angle of scoliosis between $10^{\circ}$ and $190^{\circ}$.

\section{METHODS AND PROCEDURE}

Regional ventilation/volume ratios were studied by means of clearance rates of xenon-133 $\left({ }^{133} \mathrm{Xe}\right)$. The distribution of perfusion per unit ventilated lung volume was evaluated according to Ball, Stewart, Newsham, and Bates (1962) and Anthonisen and MilicEmili (1966). The recording apparatus and the slitcollimation system, consisting of two rectangular blocks of collimators, have already been described (Bake et al., 1967; Bake, Bjure, and Widimsky, 1968).

The patients were investigated in the sitting position with the two collimation blocks placed dorsally. Each of the two rectangular blocks was positioned in the best possible way to cover the convex and concave lung respectively. Four detectors were used for each lung, the most apical about $5 \mathrm{~cm}$ from the top of the lung and the other three at $5-\mathrm{cm}$ intervals down the lung. Before each stage of the procedure the position of the collimation blocks was checked according to markings on the back of the patient. A polyethylene catheter was inserted percutaneously into the brachial vein with the tip situated approximately in the subclavian vein.

The procedure was as follows:

1. The bolus-injections of ${ }^{133} \mathrm{Xe}$ (about $0.5 \mathrm{mCi}$ ) were flushed into the bloodstream by physiological saline solution. One injection was performed during normal tidal breathing and the regional washout of xenon was continuously recorded.

2. Another xenon injection was made during breathholding at functional residual capacity (FRC). When the ${ }^{133} \mathrm{Xe}$ had reached the alveoli, the patients inhaled maximally and the regional count rates were recorded during breath-holding for about 10 seconds at total lung capacity (TLC).

3. During quiet breathing, the patients were switched $\vec{\theta}$ into a closed spirometer system containing a xenon- N air mixture. Within one minute of rebreathing (the $\square$ volume of the spirometer was kept constant by means of $\mathrm{O}_{2}$ replacement and $\mathrm{CO}_{2}$ absorption) the patient was switched out of the spirometer and during quiet air breathing the regional washout curves were recorded.

4. When background activity was low the patient $\overrightarrow{\vec{O}}$ was again switched into the xenon-air mixture in the $\exists$ spirometer. The volume in the system was kept con- $\vec{T}$ stant as before. The patient continued to rebreathe for about five minutes until the xenon concentration had reached equilibrium between the lungs and the $\overrightarrow{\vec{\sigma}}$ spirometer. Three breath-holding manoeuvres at TLC were then performed and the regional count rates. were recorded. Finally the patient was switched out $\frac{\sigma}{3}$ of the spirometer and during quiet air-breathing the washout curves were recorded.

ANALYSIS OF THE RECORDINGS The count rateso obtained at 10-second intervals during the first minute of the regional washout were plotted againsto time on semilogarithmic graph paper (background activity was subtracted). A straight line was visually $\mathcal{O}^{\circ}$ fitted to the seven points and the half-time in seconds ( $T \frac{1}{2}$ ) was calculated. $T \frac{1}{2}$ is a measure of the regionalo ventilation to volume ratio $(\dot{V} / \mathrm{V})$. In order to mini- $-\omega$ mize the effect of different overall ventilation ando lung expansion the regional ventilation/volume was also expressed as a distribution index, Dr $(\dot{V} / \mathrm{V})$ (Bake, Fugl-Meyer, and Grimby, 1972) according tow the formula:

$$
\operatorname{Dr}(\dot{\mathrm{V}} / \mathrm{V})=\frac{100}{\mathrm{~T}^{\frac{1}{2}}} \times \frac{n}{\sum \frac{1}{\mathrm{~T}^{\frac{1}{2}}}}
$$


where $n$ is the number of regions ( 8 in this study). $\operatorname{Dr}(\dot{V} / \mathrm{V})$ expresses the regional ventilation/volume ratio in percentage of the mean ventilation/volume ratios obtained from the eight regions. Thus, if the ventilation and volume were evenly distributed all $\mathrm{Dr}$ $(\dot{V} / \mathrm{V})$ would be 100.

The regional perfusion distribution index, Dr (Q́), was calculated in similar manner:

$$
\operatorname{Dr}(\dot{\mathrm{Q}})=\frac{\operatorname{CRr}(\text { inj.) } \times 100}{\operatorname{CRr}(\text { equil.) }} \times \frac{n}{\sum \frac{\operatorname{CRr} \text { (inj.) }}{\operatorname{CRr}(\text { equil.) }}}
$$

where $\mathrm{CRr}$ (inj) is the regional count rate after injection (obtained at TLC during breath-holding), $\mathrm{CRr}$ (equil) means the regional count rate during equilibrium (obtained at TLC during breath-holding) and $n$ is the number of regions (8). Thus $\operatorname{Dr}(Q)$ means the regional blood flow per unit ventilated lung volume as a percentage of the mean regional blood flow per unit ventilated lung volume for the eight regions.

\section{RESULTS}

Distribution of Ventilation Table II gives the means and corresponding standard errors for the regional half-times $\left(T \frac{1}{2}\right)$ for the three different washout procedures. We have analysed statistically the horizontally corresponding regions of the convex and concave sides of the scoliosis without finding any side-to-side differences. In addition we have analysed the side-to-side difference at the individually different horizontal levels of the apex of the curvatures without revealing any difference. Furthermore, we were unable to find any systematic difference between the washout curves obtainable after a short period of quiet breathing and those obtained after equilibration with TLC manoeuvres. Therefore, in the following presentation, we will not separate the results of the convex and concave sides or of the two washouts after inhalation of xenon. The washout procedure will subsequently be termed washout after inhalation and washout after injection.

Figure 1 illustrates the half-times after inhalation and after injection for all patients below 40 years of age. The half-times obtained after an injection of xenon show a normal progressive decrease from apex to base in patients with curvatures of less than $100^{\circ}$. However, in the two basal regions the half-times were significantly longer after inhalation than after injection, irrespective of the severity of the scoliosis. This difference was significant also in apical regions in patients with curvatures $\geqslant 100^{\circ}$.

Figure 2 illustrates the corresponding comparison for all patients over 40 years of age. Although the general impression is that the half-times after injection are shorter than after inhalation, no

T A B L E I I

WASHOUT DATA AFTER INHALATION, AFTER EQUILIBRATION, AND AFTER INJECTION OF ${ }^{133}$ Xe: MEANS AND STANDARD ERRORS OF THE MEANS

\begin{tabular}{|c|c|c|c|c|c|c|c|c|c|c|}
\hline \multirow{2}{*}{$\begin{array}{l}\text { Angle of } \\
\text { Scoliosis }\end{array}$} & \multirow{2}{*}{$\begin{array}{l}\text { Age } \\
(y r)\end{array}$} & \multirow{2}{*}{$\begin{array}{l}\text { No. of } \\
\text { Patients }\end{array}$} & \multicolumn{4}{|c|}{ Convex Side of Scoliosis From Top of Lung (cm) } & \multicolumn{4}{|c|}{ Concave Side of Scoliosis From Top of Lung $(\mathrm{cm})$} \\
\hline & & & 5 & 10 & 15 & 20 & 5 & 10 & 15 & 20 \\
\hline & & & \multicolumn{8}{|c|}{ Washout after inhalation ( $\mathrm{T} \frac{1}{2}$ sec.) } \\
\hline$<60^{\circ}$ & $\begin{array}{l}<40 \\
\geqslant 40\end{array}$ & $\begin{array}{r}8 \\
12\end{array}$ & $\begin{array}{l}37 \pm 4 \\
46 \pm 5\end{array}$ & $\begin{array}{l}31 \pm 4 \\
35 \pm 4\end{array}$ & $\begin{array}{l}30 \pm 3 \\
26 \pm 3\end{array}$ & $\begin{array}{l}34 \pm 3 \\
31 \pm 2\end{array}$ & $\begin{array}{l}39 \pm 4 \\
45 \pm 5\end{array}$ & $\begin{array}{l}30 \pm 3 \\
33 \pm 3\end{array}$ & $\begin{array}{l}32 \pm 3 \\
28 \pm 3\end{array}$ & $\begin{array}{l}31 \pm 2 \\
29 \pm 2\end{array}$ \\
\hline $60-99^{\circ}$ & $\begin{array}{l}<40 \\
\geqslant 40\end{array}$ & $\begin{array}{l}5 \\
5\end{array}$ & $\begin{array}{l}26 \pm 6 \\
30 \pm 3\end{array}$ & $\begin{array}{l}21 \pm 6 \\
21 \pm 2\end{array}$ & $\begin{array}{l}21 \pm 4 \\
26 \pm 3\end{array}$ & $\begin{array}{l}21 \pm 5 \\
32 \pm 5\end{array}$ & $\begin{array}{l}31 \pm 2 \\
36 \pm 5\end{array}$ & $\begin{array}{l}18 \pm 3 \\
27 \pm 5\end{array}$ & $\begin{array}{l}20 \pm 4 \\
20 \pm 3\end{array}$ & $\begin{array}{l}22 \pm 4 \\
29 \pm 6\end{array}$ \\
\hline \multirow[t]{2}{*}{$\geqslant 100^{\circ}$} & $\begin{array}{l}<40 \\
\geqslant 40\end{array}$ & $\begin{array}{l}7 \\
5\end{array}$ & $\begin{array}{l}39 \pm 6 \\
32 \pm 6\end{array}$ & $\begin{array}{l}32 \pm 4 \\
29 \pm 6\end{array}$ & $\begin{array}{l}32 \pm 3 \\
29 \pm 5\end{array}$ & $\begin{array}{l}40 \pm 6 \\
41 \pm 12\end{array}$ & $\begin{array}{l}39 \pm 4 \\
33 \pm 7\end{array}$ & $\begin{array}{l}29 \pm 4 \\
27 \pm 3\end{array}$ & $\begin{array}{l}28 \pm 4 \\
25 \pm 4\end{array}$ & $\begin{array}{l}37 \pm 5 \\
40 \pm 11\end{array}$ \\
\hline & & & \multicolumn{8}{|c|}{ Washout after equilibration ( $T_{\frac{1}{2}}$ sec.) } \\
\hline$<60^{\circ}$ & $\begin{array}{l}<40 \\
\geqslant 40\end{array}$ & $\begin{array}{r}8 \\
12\end{array}$ & $\begin{array}{l}32 \pm 3 \\
39 \pm 5\end{array}$ & $\begin{array}{l}26 \pm 4 \\
41 \pm 4\end{array}$ & $\begin{array}{l}27 \pm 2 \\
33 \pm 3\end{array}$ & $\begin{array}{l}32 \pm 2 \\
28 \pm 3\end{array}$ & $\begin{array}{l}40 \pm 4 \\
45 \pm 5\end{array}$ & $\begin{array}{l}27 \pm 1 \\
37 \pm 4\end{array}$ & $\begin{array}{l}28 \pm 2 \\
33 \pm 3\end{array}$ & $\begin{array}{l}28 \pm 2 \\
32 \pm 4\end{array}$ \\
\hline $60-99^{\circ}$ & $\begin{array}{l}<40 \\
\geqslant 40\end{array}$ & $\begin{array}{l}5 \\
5\end{array}$ & $\begin{array}{l}29 \pm 3 \\
32 \pm 5\end{array}$ & $\begin{array}{l}21 \pm 3 \\
28 \pm 4\end{array}$ & $\begin{array}{l}22 \pm 2 \\
30 \pm 7\end{array}$ & $\begin{array}{l}24 \pm 4 \\
38 \pm 6\end{array}$ & $\begin{array}{l}32 \pm 6 \\
34 \pm 4\end{array}$ & $\begin{array}{l}20 \pm 3 \\
25 \pm 3\end{array}$ & $\begin{array}{l}22 \pm 3 \\
22 \pm 3\end{array}$ & $\begin{array}{l}22 \pm 2 \\
30 \pm 5\end{array}$ \\
\hline \multirow[t]{2}{*}{$\geqslant 100^{\circ}$} & $\begin{array}{l}<40 \\
\geqslant 40\end{array}$ & $\begin{array}{l}7 \\
5 \\
\end{array}$ & $\begin{array}{l}31 \pm 4 \\
45 \pm 9\end{array}$ & $\begin{array}{l}28 \pm 4 \\
28 \pm 7 \\
\end{array}$ & $\begin{array}{l}28 \pm 2 \\
30 \pm 6\end{array}$ & $\begin{array}{l}34 \pm 4 \\
55 \pm 16 \\
\end{array}$ & $\begin{array}{l}35 \pm 3 \\
38 \pm 7\end{array}$ & $\begin{array}{l}24 \pm 2 \\
30 \pm 4\end{array}$ & $\begin{array}{l}25 \pm 3 \\
31 \pm 6\end{array}$ & $\begin{array}{l}44 \pm 8 \\
46 \pm 7\end{array}$ \\
\hline & & & \multicolumn{8}{|c|}{ Washout after injection ( $T \frac{1}{2}$ sec.) } \\
\hline$<60^{\circ}$ & $\begin{array}{l}<40 \\
\geqslant 40\end{array}$ & $\begin{array}{r}8 \\
12\end{array}$ & $\begin{array}{l}37 \pm 5 \\
28 \pm 2\end{array}$ & $\begin{array}{l}30 \pm 4 \\
32 \pm 4\end{array}$ & $\begin{array}{l}23 \pm 3 \\
25 \pm 2\end{array}$ & $\begin{array}{l}21 \pm 3 \\
21 \pm 2\end{array}$ & $\begin{array}{l}33 \pm 3 \\
38 \pm 7\end{array}$ & $\begin{array}{l}29 \pm 3 \\
31 \pm 3\end{array}$ & $\begin{array}{l}25 \pm 4 \\
24 \pm 2\end{array}$ & $\begin{array}{l}21 \pm 2 \\
22 \pm 2\end{array}$ \\
\hline $60-99^{\circ}$ & $\begin{array}{l}<40 \\
\geqslant 40\end{array}$ & $\begin{array}{l}5 \\
5\end{array}$ & $\begin{array}{l}27 \pm 6 \\
23 \pm 4\end{array}$ & $\begin{array}{l}24 \pm 6 \\
22 \pm 5\end{array}$ & $\begin{array}{l}15 \pm 3 \\
20 \pm 1\end{array}$ & $\begin{array}{l}11 \pm 1 \\
22 \pm 1\end{array}$ & $\begin{array}{l}32 \pm 3 \\
22 \pm 3\end{array}$ & $\begin{array}{l}17 \pm 3 \\
20 \pm 3\end{array}$ & $\begin{array}{l}15 \pm 2 \\
15 \pm 2\end{array}$ & $\begin{array}{l}14 \pm 2 \\
23 \pm 5\end{array}$ \\
\hline$\geqslant 100^{\circ}$ & $\begin{array}{l}<40 \\
\geqslant 40\end{array}$ & $\begin{array}{l}7 \\
6\end{array}$ & $\begin{array}{l}25 \pm 3 \\
23 \pm 3\end{array}$ & $\begin{array}{l}20 \pm 2 \\
22 \pm 4\end{array}$ & $\begin{array}{l}21 \pm 2 \\
23 \pm 4\end{array}$ & $\begin{array}{l}20 \pm 2 \\
33 \pm 5\end{array}$ & $\begin{array}{l}26 \pm 2 \\
29 \pm 4\end{array}$ & $\begin{array}{l}20 \pm 2 \\
21 \pm 3\end{array}$ & $\begin{array}{l}17 \pm 2 \\
23 \pm 3\end{array}$ & $\begin{array}{l}20 \pm 3 \\
29 \pm 4\end{array}$ \\
\hline
\end{tabular}




$$
<40 y r s
$$$$
\begin{array}{ll}
\square T_{1 / 2} & \text { after inhalation } \\
\Delta T_{1 / 2} & \text { after injection }
\end{array}
$$$$
<60^{\circ}
$$

$60^{\circ}-99^{\circ}$

sec

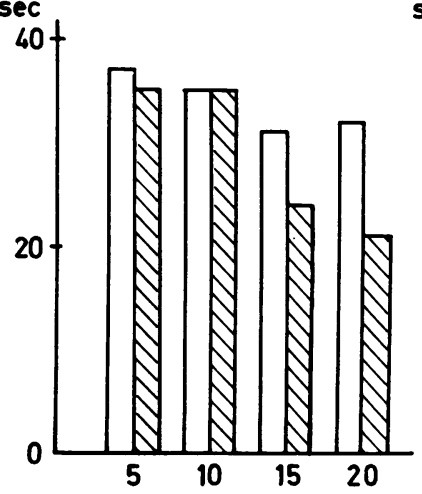

sec

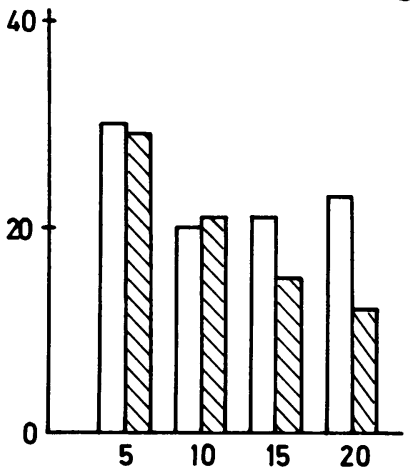

sec

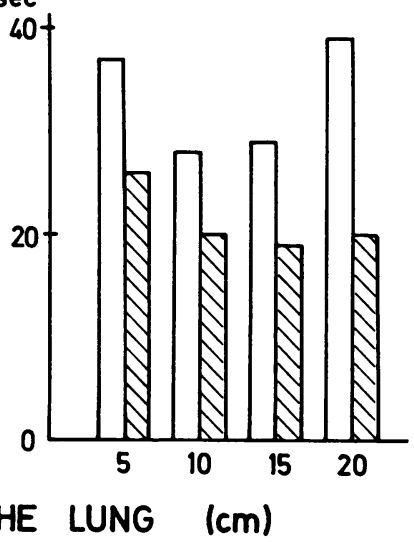

FIG. 1. Comparison between half-times (sec.) after injection and after inhalation for all patients below 40 years of age.

$\geq 40 \mathrm{yrs}$

$$
\begin{aligned}
& \Delta T_{1 / 2} \text { after inhalation } \\
& \nabla T_{1 / 2} \text { after injection }
\end{aligned}
$$

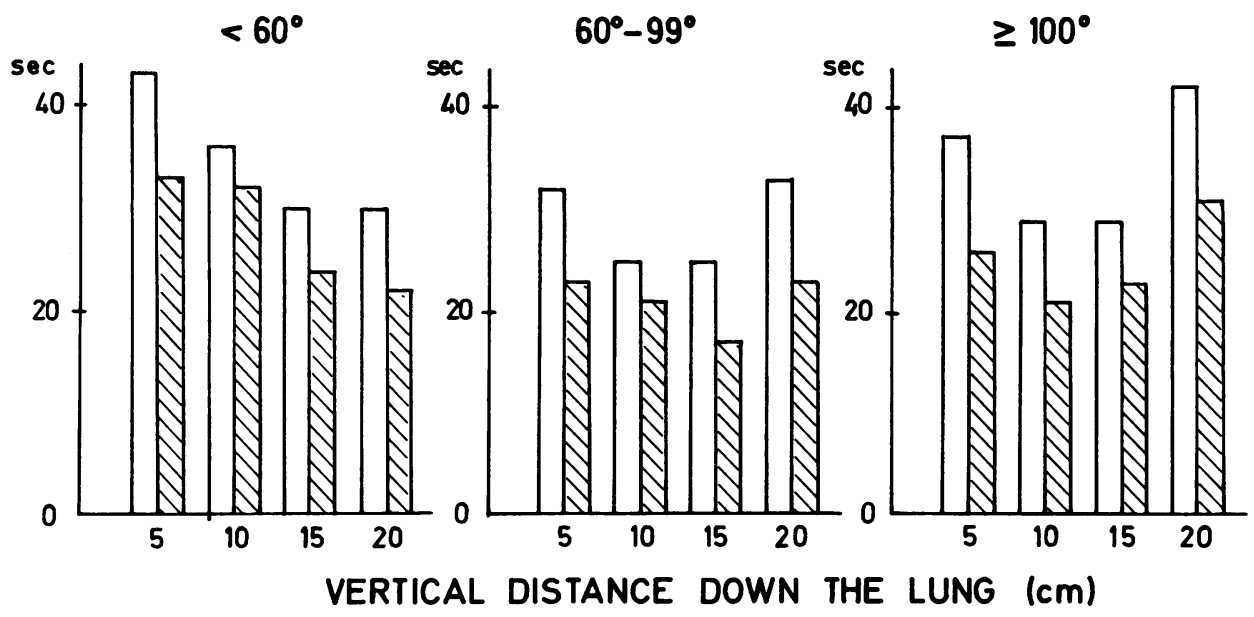

FIG. 2. Comparison between half-times (sec.) after injection and after inhalation for all patients over 40 years of age. 
$\mathrm{cm}$ from the
top of the lung $\mathrm{cm}$ from the

top of the lung

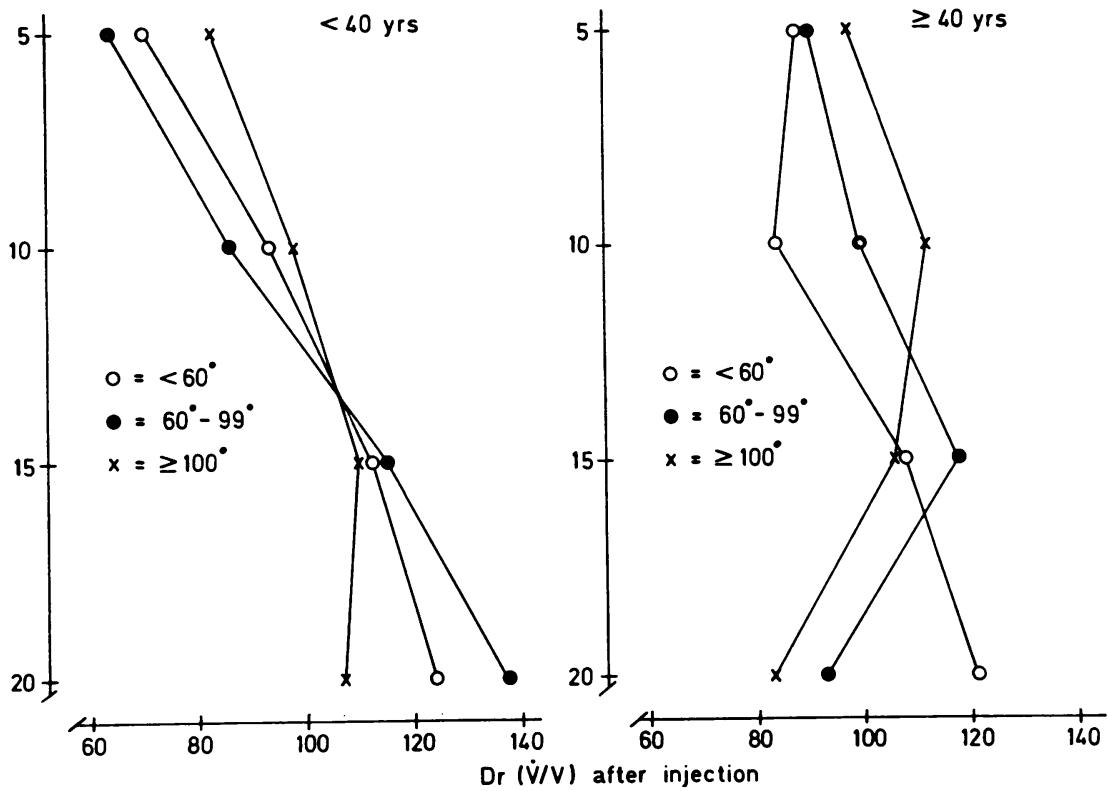

FIG. 3. Ventilation/volume distribution after injection related to increasing angulation of the curvature for patients below and above 40 years of age.

statistically significant differences were found in patients with curvatures of more than $100^{\circ}$, whereas those with smaller curvatures showed differences in some regions. As pointed out previously, half-times may be influenced by overall differences of ventilation or degree of lung expansion. In particular, the successive reduction of FRC with increasing angle of scoliosis would make comparisons between $\mathrm{T} \frac{1}{2}$ values difficult. In order to minimize these effects when comparing different groups of patients, we also express our data as distribution indices, $\mathrm{Dr}(\mathbf{V} / \mathrm{V})$.

Figure 3 illustrates the effect of increasing severity of scoliosis on the ventilation/volume distribution obtained after injection for younger and older patients. The younger patients seem to be affected only when the degree of curvature exceeds $100^{\circ}$; there is a reduction of basal ventilation/volume distribution with increasing severity of scoliosis $(r=-0.42, P>0.05)$. The older patients tend to have more abnormal distribution profiles and show a progressive fall in basal ventilation/volume ratios with increasing curvatures $(r=-0.54, P<0.05)$. In the most basal region, subjects over 40 years of age and those with curvatures above $60^{\circ}$ had significantly lower ratios than other subjects.

Figure 4 illustrates the corresponding ventilation/volume distribution profiles obtained after inhalation. For the older patients in the most basal region, there was a successively reduced ventilation/volume ratio with increasing severity of scoliosis $(\mathrm{r}=-0.65, \mathrm{P}<0.05)$, which could not be demonstrated for the younger patients $(r=-0.29$, $P>0.05)$.

DISTRIBUTION OF PERfUSION Table III gives the means and standard errors of the means for the regional perfusion distribution indices, $\operatorname{Dr}(\mathrm{Q})$. As for ventilation/volume distribution, the sideto-side analyses revealed no systematic differences and only the means of the corresponding regions of the convex and concave sides will be taken into account in the following presentation.

Figure 5 illustrates the perfusion distribution profiles for younger and older patients. When the most basal regions $(20 \mathrm{~cm}$ from the top of the lung) are compared with the regions $15 \mathrm{~cm}$ from the top, basal perfusion is significantly decreased in patients from both age groups with the most 


$$
\begin{aligned}
& \mathrm{cm} \text { from the } \\
& \text { top of the lung }
\end{aligned}
$$

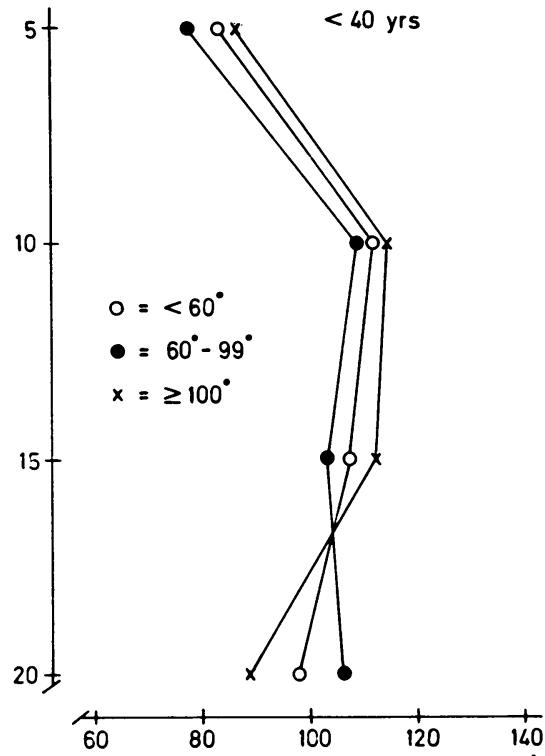

$\mathrm{cm}$ from the

top of the lung

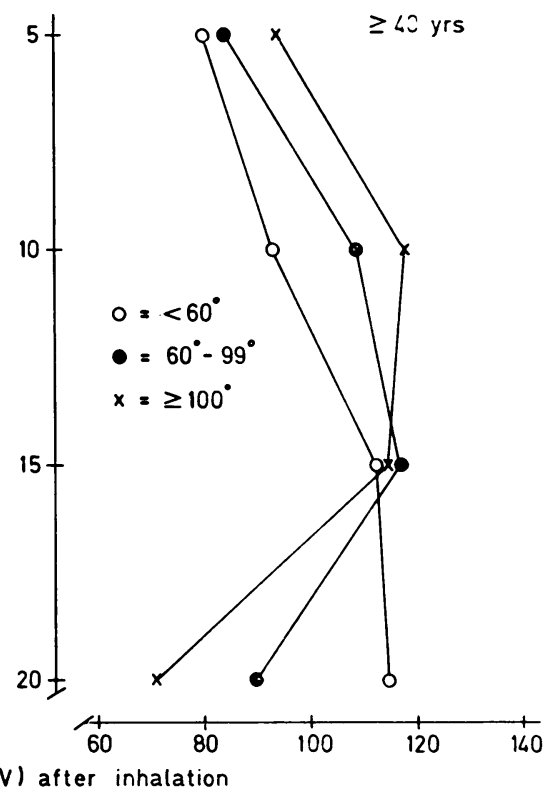

FIG. 4. Ventilation/volume distribution after inhalation for patients below and above 40 years of age.

severe deformities. In the most basal region there was a successively decreasing perfusion with increasing curvature for the younger patients $(\mathrm{r}=-0.72, \mathrm{P}<0.05)$ and for the older patients $(\mathrm{r}=-0.56, \mathrm{P}<0.05)$.

\section{DISCUSSION}

The general errors of the method have been analysed by Ball et al. (1962) and by Matthews and Dollery (1965). A major drawback in the present study is that the available collimation system inadequately separates the convex and concave lung in patients with the most advanced spinal deformities, a fact which may explain the $\stackrel{\mathbb{2}}{\varrho}$ absence of side-to-side differences. However, the $\overrightarrow{\overrightarrow{0}}$ main concern in this study was the vertical distri- 3 bution in the upright position. With increasing severity of scoliosis, the distance from the lung. apex to the base will necessarily become shorter. Any detector with a fixed relation to the apex of the lungs, as in the present study, will therefore $x$ not register quite comparable lung regions in slight $\frac{7}{7}$ and severe scoliosis. The vertical distribution of ventilation and perfusion within the lungs is $\delta$ related to gravitational forces (West, Dollery, and 2 Naimark, 1964; Milic-Emili et al., 1966) and 을 therefore to vertical distance down the lung rather $D$

T A B L E I I I

\begin{tabular}{|c|c|c|c|c|c|c|c|c|c|c|}
\hline \multirow{2}{*}{$\begin{array}{l}\text { Angle of } \\
\text { Scoliosis }\end{array}$} & \multirow{2}{*}{$\begin{array}{l}\text { Age } \\
(y r)\end{array}$} & \multirow{2}{*}{$\begin{array}{l}\text { No. of } \\
\text { Patients }\end{array}$} & \multicolumn{4}{|c|}{ Convex Side of Scoliosis From Top of Lung (cm) } & \multicolumn{4}{|c|}{ Concave Side of Scoliosis From Top of Lung $(\mathrm{cm})$} \\
\hline & & & 5 & 10 & 15 & 20 & 5 & 10 & 15 & 20 \\
\hline & & & \multicolumn{8}{|c|}{ Perfusion distribution, $\mathrm{Dr}(\dot{\boldsymbol{Q}})$} \\
\hline$<60^{\circ}$ & $\begin{array}{l}<40 \\
\geqslant 40\end{array}$ & $\begin{array}{r}8 \\
12\end{array}$ & $\begin{array}{l}52 \pm 5 \\
72 \pm 10\end{array}$ & $\begin{array}{l}85 \pm 7 \\
82 \pm 6\end{array}$ & $\begin{array}{l}119 \pm 6 \\
117 \pm 4\end{array}$ & $\begin{array}{l}142 \pm 8 \\
129 \pm 6\end{array}$ & $\begin{array}{l}49 \pm 4 \\
66 \pm 5\end{array}$ & $\begin{array}{l}86 \pm 5 \\
81 \pm 3\end{array}$ & $\begin{array}{l}130 \pm 7 \\
116 \pm 5\end{array}$ & $\begin{array}{l}138 \pm 10 \\
137 \pm 9\end{array}$ \\
\hline $60-99^{\circ}$ & $\begin{array}{l}<40 \\
\geqslant 40\end{array}$ & $\begin{array}{l}5 \\
5\end{array}$ & $\begin{array}{l}74 \pm 11 \\
70 \pm 6\end{array}$ & $\begin{array}{l}86 \pm 4 \\
85 \pm 3\end{array}$ & $\begin{array}{l}116 \pm 3 \\
103 \pm 10\end{array}$ & $\begin{array}{l}135 \pm 9 \\
132 \pm 10\end{array}$ & $\begin{array}{l}65 \pm 4 \\
67 \pm 8\end{array}$ & $\begin{array}{l}86 \pm 7 \\
91 \pm 7\end{array}$ & $\begin{array}{l}110 \pm 6 \\
124 \pm 9\end{array}$ & $\begin{array}{l}128 \div 5 \\
126 \pm 9\end{array}$ \\
\hline$\geqq 100^{\circ}$ & $\begin{array}{l}<40 \\
\geqslant 40\end{array}$ & $\begin{array}{l}7 \\
6\end{array}$ & $\begin{array}{l}85 \pm 10 \\
75 \pm 4\end{array}$ & $\begin{array}{r}94 \pm 7 \\
104 \pm 5\end{array}$ & $\begin{array}{l}116 \pm 6 \\
121 \pm 11\end{array}$ & $\begin{array}{l}111 \pm 11 \\
105 \pm 6\end{array}$ & $\begin{array}{l}67 \pm 7 \\
75 \pm 5\end{array}$ & $\begin{array}{r}96 \pm 4 \\
106 \pm 4\end{array}$ & $\begin{array}{l}121 \pm 9 \\
122 \pm 3\end{array}$ & $\begin{array}{r}108 \div 9 \\
93 \doteqdot 7\end{array}$ \\
\hline
\end{tabular}

REGIONAL PERFUSION DISTRIBUTION INDICES: MEANS AND STANDARD ERRORS OF THE MEAN 
$\mathrm{cm}$ from the

top of the lung $\mathrm{cm}$ from the

top of the lung
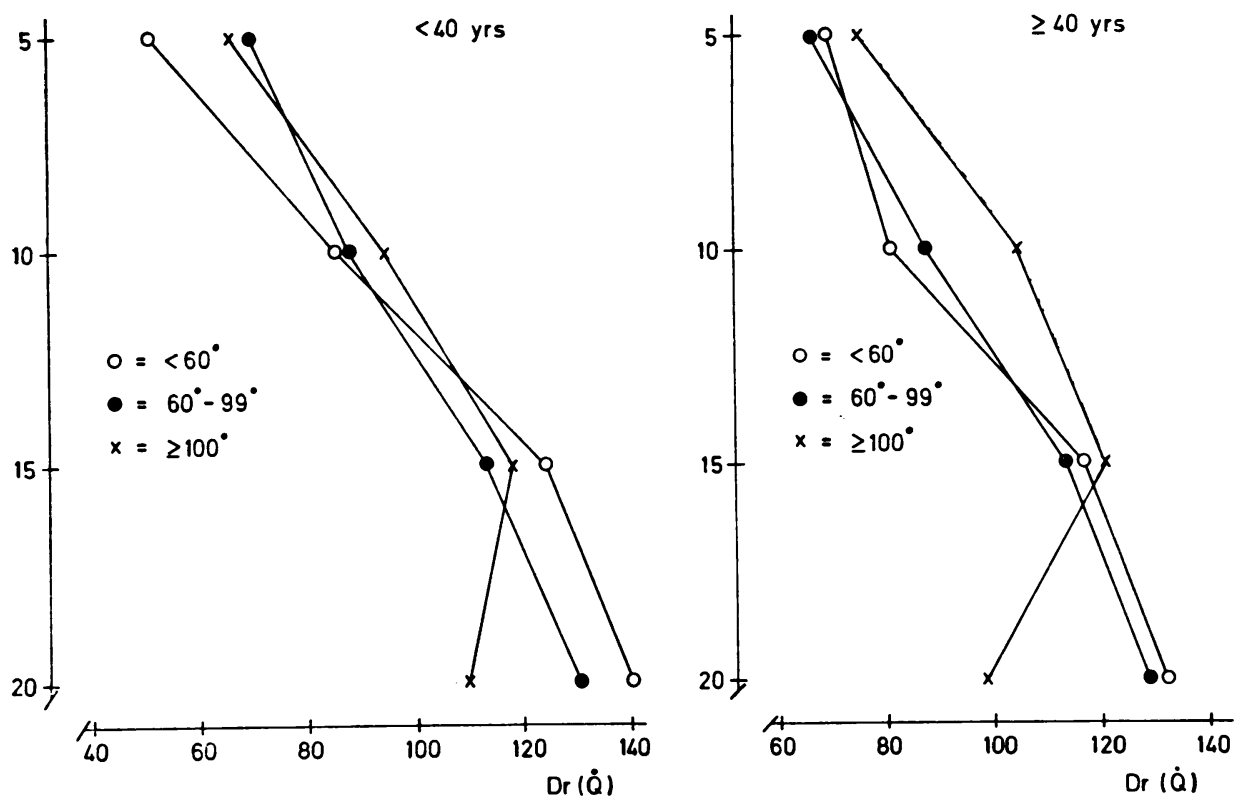

FIG. 5. Perfusion distribution related to increasing angulation of the curvature for patients below and above 40 years of age.

than to anatomical subdivisions. Furthermore, satisfactory count rates were usually recorded only at the lung base in the group with the most severe scoliosis.

REGIONAL DISTRIBUTION OF VENTILATION The regional half-times $\left(\mathrm{T} \frac{1}{2}\right)$ obtained from washout curves are inversely proportional to the regional ventilation/volume ratios. Normally the half-times decrease down the lung because the ventilation increases and the volume (degree of lung expansion) decreases from upper to dependent parts of the lungs (Bryan et al., 1964 ; Milic-Emili et al., 1966).

Washouts were studied after xenon had been inhaled by two different types of breathing manoeuvre. No differences between the corresponding half-times were found. However, it should be kept in mind that the washout curves were analysed only during the first minute (because of the background interference with later parts of the curves) and were approximated to uniexponential curves. Therefore, alveoli with very low ventilation/volume ratios relative to the mean ratio within a region are likely to be undetected.
The distribution of ventilation to volume ratios was clearly related to the degree of spinal deformity, whether analysed after injection or inhalation of xenon. The main abnormality seemed to be a progressive decrease in basal ventilation/volume ratio with increasing severity of scoliosis.

According to the results from inhalation washouts, the basal reduction was apparent to some extent also in patients with the smallest curvatures and was similar for younger and older patients. Results obtained after intravenous injection of xenon differed from that after inhalation. The clearance rates after injection seemed to be agedependent. They were normal for the two groups of patients below 40 years of age with curvatures below $100^{\circ}$. The younger patients with deformities above $100^{\circ}$ and the older patients with curvatures above $60^{\circ}$ showed evidence of basal hypoventilation as judged from washouts after injection of xenon as well as after inhalation. These results confirm and extend the previous reports by Dollery et al. (1965) and Shannon et al. (1970), who also found basal reduction in some of their kyphoscoliotic patients.

The decrease in basal ventilation/volume ratio 
could be due to either decreased basal ventilation or increased volume (i.e., lung expansion). To our knowledge there are no reports indicating a systematically increased degree of alveolar expansion in the basal parts of the lungs in scoliotic patients. Bergofsky et al. (1959) point out that alveoli may be smaller or larger than normal and that these abnormalities are irregularly distributed within a lung and within each lobe. Furthermore, in most of our patients we have also measured the regional distribution of a vital capacity (VC), which gives an indication of the regional VC/TLC ratio. This ratio was normally distributed in most patients and did not change with increasing angle of scoliosis. Therefore, we feel that the basal decrease in ventilation/volume ratio reflects relative basal hypoventilation.

Different mechanisms could account for decreased basal ventilation, whereby the behaviour of the basal parts of the lungs are changed in relation to the rest of the lungs-decreased relative basal compliance, increased relative basal airway resistance, and finally reduced basal transpulmonary pressure changes associated with tidal breathing. We are unable to distinguish between these three possibilities on the basis of available data.

Using the ${ }^{133} \mathrm{Xe}$ method described by Dollfuss, Milic-Emili, and Bates (1967), we have previously reported evidence of airway closure at lung volumes greater than functional residual capacity (FRC) in 17 of 40 patients with scoliosis (Bjure et al., 1970). This indicates that some airways close during normal breathing. Six of these 17 patients were under the age of 40 years and all of them had scoliosis exceeding an angle of $90^{\circ}$. Thirtysix patients participated in both the previous and present studies. A significant inverse correlation was found between closing volume above FRC and the basal ventilation/volume ratio on the convex side, the coefficients being -0.41 and -0.38 for washouts after injection and inhalation respectively. These findings may indicate that airway closure occurs in basal regions on the convex side.

REGIONAL DISTRIBUTION OF BLOOD FLOW Normally the vertical distribution of blood flow within the lungs is uneven, the upper parts receiving less blood flow per unit lung volume than dependent parts, mainly because the pressure differences determining flow increase down the lung (i.e., the difference in pressures between either pulmonary artery and vein or pulmonary artery and alveoli) (West et al., 1964). Dollery et al., (1965) and Shannon et al. (1970), using ${ }^{133} \mathrm{Xe}$ technique, reported abnormally even blood flow distribution $\frac{\vec{F}}{0}$ in patients with scoliosis. Our results indicate $\frac{C}{0}$ normal distribution profiles in most patients with deformities less than $60^{\circ}$ and successively more ${ }_{\mathbb{\infty}}$ even distribution with increasing angle of scoliosis, $\cong$ primarily because of decreased basal blood flow. ¿

The observed apico-basal blood flow distribu- $\overrightarrow{0}$ tion may be explained by generalized increased $\overrightarrow{-}$ pulmonary vascular resistance or elevated pul- $\vec{\omega}$ monary pressure, which would tend to equalize apico-basal differences in regional perfusion pres- $\vec{x}$ sures. It is also conceivable that there is a selective $N$ increase in basal vascular resistance.

With advancing disease these patients have pul-ðे monary artery hypertension (Bergofsky et al., 1959) which would tend to make the regional per-을 fusion pressures more equal between apical and ${ }_{z}^{-}$ basal regions. The morphometric measurements re-o ported by Reid (1969) indicate an abnormally small vascular cross-sectional area, but without basal 3 predilection. Dollery et al. (1965) draw attention® to the effect of the reduced height of the lungs $\overrightarrow{0}$ in these patients which may increase apical per-N fusion pressure and therefore apical blood flow: Shannon et al. (1970) discussed the implicationso of interdependence between lung expansion and vascular resistance on the regional distribution of blood flow with the effect of increasing vascularo resistance in the basal regions. These principles@ have been established in normal subjects (Hughes, $\overrightarrow{0}$ Glazier, Maloney, and West, 1968).

The present results do not exclude any of the? above-mentioned mechanisms. However, it seems. unlikely that equalized apico-basal perfusion pres sure is the only responsible factor because in응 patients with the most severe deformities the shape of the distribution profiles indicates selectivelyo reduced basal flow. Therefore, the basal vascular resistance may be preferentially increased at leastô in severe scoliosis.

The clinical investigation (Bjure et al., 1970) revealed that dyspnoea increased with increasing curvature (Table I). Figure 6 (left) illustrates the ventilation/volume distribution for three differentr degrees of dyspnoea (I to $\mathrm{V}$ as defined in Table I) Only patients with an angle of scoliosis above $60^{\circ} \mathrm{N}$ are included in order to minimize angle differences $N_{\omega}^{N}$ In the first group $(\mathrm{I}+\mathrm{II})$ the mean angle is $87^{\circ} \mathrm{O}$ and mean age 35 years; in the second group (III) $112^{\circ}$ and 32 years; and in the third group $(\mathrm{IV}+\mathrm{V})$ $119^{\circ}$ and 53 years. The ventilation/volume distri $\stackrel{0}{?}$ bution after injection indicates that patients suffer -0 ing from severe dyspnoea $(\mathrm{IV}+\mathrm{V})$ have an ab normal regional ventilation/volume distribution $\overrightarrow{\mathbb{D}}$ but this difference may be partly explained by the age difference. 


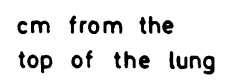

$\mathrm{cm}$ from the
top of the lung $\mathrm{cm}$ from the

top of the lung
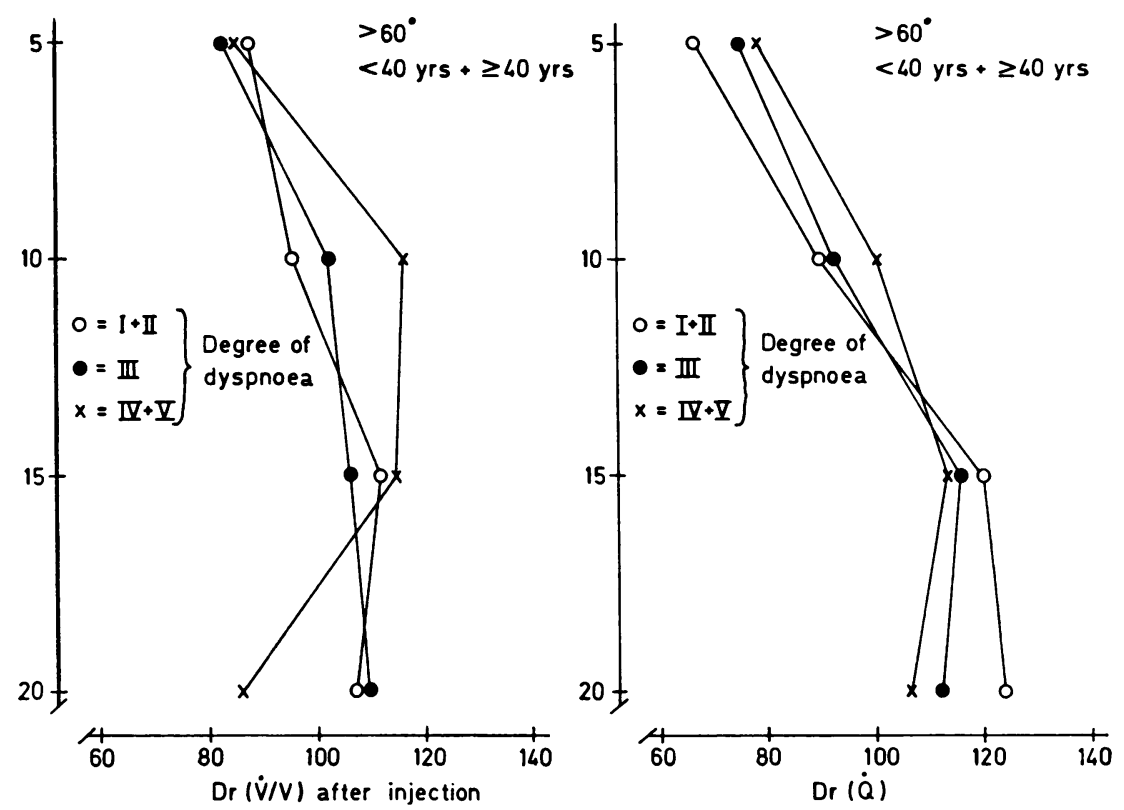

FIG. 6. Ventilation/volume distribution after injection and perfusion distribution for three degrees of dyspnoea for all patients with angles of scoliosis above $60^{\circ}$.

INTRAREGIONAL DISTRIBUTION OF VENTILATION AND BLOOD FLOW Regional washout curves obtained after an intravenous injection of xenon reflect mainly perfused alveoli (Bentivoglio et al., 1963), whereas corresponding curves obtained after inhalation of xenon also reflect non-perfused units. Discrepancies between these two clearance rates have been reported, for example, in chronic bronchitis (Anthonisen et al., 1968), but no such abnormalities were found in asthmatic patients (Heckscher et al., 1968).

In the present study, the washout rate after xenon injection was not the same as after xenon inhalation (Figs 1 and 2). This difference suggests uneven ventilation within a region. When xenon is injected intravenously, well perfused alveoli within a region will receive more xenon than low perfused alveoli and the subsequent washout rate will reflect mainly these well perfused alveoli. On the other hand, when xenon is inhaled during rebreathing, perfused and non-perfused as well as ventilated and poorly ventilated alveoli will receive xenon and the subsequent washout rate reflects to some extent the ventilation of the average alveolus in the region. Our results show generally more rapid washouts after injection than after inhalation of xenon. Therefore, within the inhomogeneously ventilated region, well perfused alveoli seemed to be well ventilated, which would tend to reduce intraregional ventilation/ perfusion inequalities.

This adjustment within regions between distribution of blood flow and ventilation volume ratios was most obvious in the younger patients with the most severe deformities (Fig. 1). In the older patients with angles of scoliosis exceeding $100^{\circ}$ no evidence of intraregional ventilation inhomogeneity was found since there were not statistically significant differences between the clearance rates after inhalation and intravenous injection of xenon. However, it should be pointed out that if the blood flow within a region is evenly distributed no differences between washouts after injection and inhalation will be observed despite ventilation inequalities. The abnormal clearance rates after inhalation of xenon were independent of age (Table II ; Figs 1, 2, and 4) since no significant differences were found between the younger and older patients. This is not in keeping with the suggestion that intraregional inhomogeneity decreases with increasing age. Therefore, we feel that at least in severe scoliosis the most likely interpretation is that there is considerable inhomogeneity of ventilation/volume ratios within regions 
irrespective of age and that the blood flow distribution within regions is more effectively adjusted to ventilation in the younger patients than in the older.

In conclusion, our results suggest that the regional distribution of ventilation and blood flow in scoliotic patients is related to the severity of the deformity which acts by reducing the basal lung function. As these abnormalities tend to run in parallel, they do not seem to contribute to the impaired gas exchange known to occur particularly in middle-aged patients with severe scoliosis. But our data also suggest considerable inhomogeneities within regions in conformity with the irregularity of the vascular and alveolar abnormalities demonstrated by Reid (1969). However, particularly in the young severe scoliotic patient, the blood flow distribution within regions seemed to be adjusted to the intraregional ventilation, thereby reducing ventilation to perfusion inhomogeneities. On the other hand, in the older severe scoliotic patient, the intraregional adjustment appeared to be insignificant. These observations may help to explain why older patients with scoliosis tend to have more impaired gas exchange than younger patients.

The authors are indebted to Professor J. Milic-Emili for valuable advice and criticism.

This study was supported by a grant from the Swedish National Association against Heart and Chest Diseases and from the First of May Flower Annual Campaign for Children's Health.

\section{REFERENCES}

Anthonisen, N. R., Bass, H., Oriol, A., Place, R. E. G., and Bates, D. V. (1968). Regional lung function in patients with chronic bronchitis. Clin. Sci., 35, 495.

_ and Milic-Emili, J. (1966). Distribution of pulmonary perfusion in erect man. J. appl. Physiol., 21, 760.

Bake, B., Bjure, J., Grimby, G., Milic-Emili, J., and Nilsson, N. J. (1967). Regional distribution of inspired gas in supine man. Scand. J. resp. Dis., 48, 189.

,-- , and Widimsky, J. (1968). The effect of sitting and graded exercise on the distribution of pulmonary blood flow in healthy subjects studied with ${ }^{133}$ Xenon technique. Scand. J. clin. Lab. Invest., 22, 99.

_- Fugl-Meyer, A., and Grimby, G. (1972). Breathing pattern and regional ventilation distribution in tetraplegic patients and in normal subjects. Clin. Sci. 42, 117.

Ball, W. C. Jr., Stewart, P. B., Newsham, L. G. S., and Bates, D. V. (1962). Regional pulmonary function studied with ${ }^{133}$ Xenon. J. clin. Invest., 41, 519.

Bentivoglio, L. G., Beerel, F., Stewart, P. B., Bryan, A. C., Ball, W. C., and Bates, D. V. (1963). Studies of regional ventilation and perfusion in pulmonary emphysema using Xenon ${ }^{133}$. Amer. Rev. resp. Dis., 88, 315.

Bergofsky, E. H., Turino, G. M., and Fishman, A. P. (1959). Cardiorespiratory failure in kyphoscoliosis. Medicine (Baltimore), 38, 263.
Bjure, J., Grimby, G., Kasalichý, J., Lindh, M., and Nachemson, A. (1970). Respiratory impairment and airway closure in patients with untreated idiopathic scoliosis. 흐 Thorax, 25, 451.

,-- , and Nachemson, A. (1968). Correction of body $\stackrel{\nabla}{\vec{D}}$ height in predicted spirometric values in scoliotic patients. Scand. J. clin. Lab. Invest., 21, 190.

Bruderman, I., and Stein, M. (1961). Physiologic evaluation $\vec{\circ}$ and treatment of kyphoscoliotic patients. Ann. intern. Med., 55, 94.

Bryan, A. C., Bentivoglio, L. G., Beerel, F., MacLeish, H., Zidulka, A., and Bates, D. V. (1964). Factors affecting regional distribution of ventilation and perfusion in the lung. J. appl. Physiol., 19, 395.

College of General Practitioners (1961). Chronic bronchitis in Great Britain. Brit. med. J. 2. 973.

Dollery, C. T., Gillam, P. M. S., Hugh-Jones, P., and Zorab, P. A. (1965). Regional lung function in kypho-음 scoliosis. Thorax, 20, 175.

Dollfuss, R. E., Milic-Emili, J., and Bates, D. V. (1967).Z Regional ventilation of the lung, studied with boluses of ${ }^{133}$ Xenon. Resp. Physiol., 2, 234.

Fishman, A. P. (1965). Pulmonary aspects of scoliosis. In Proc. Symp. Scoliosis, edited by P. A. Zorab, pp. 52-53. D National Fund for Research into Poliomyelitis and other Crippling Diseases. Vincent House, London.

Hanley, T., Platts, M. M., Clifton, M., and Morris, T. L.N (1958). Heart failure of the hunchback. Quart. J. Med., 27, 155.

Heckscher, T., Bass, H., Oriol, A., Rose, B., Anthonisen, N. R., and Bates, D. V. (1968). Regional lung functiono in patients with bronchial asthma. J. clin. Invest., 47, 1063.

Hughes, J. M. B., Glazier, J. B., Maloney, J. E., and West, J. B. (1968). Effect of lung volume on the distribution of pulmonary blood flow in man. Resp. Physiol., 4, 58.

Makley, J. T., Herndon, C. H., Inkley, S., Doershuk, C., Matthews, L. W., Post, R. H., and Littell, A. S. (1968). Pulmonary function in paralytic and non-paralytic scoliosis before and after treatment. J. Bone Jt Surg., 50, A, 1379.

Matthews, C. M. E., and Dollery, C. T. (1965). Interpretation: of ${ }^{133} \mathrm{Xe}$ lung wash-in and wash-out curves using an analogue computer. Clin. Sci., 28, 573.

Milic-Emili, J., Henderson, J. A. M., Dolovich, M. B.,̊ Trop, D., and Kaneko, K. (1966). Regional distribution of inspired gas in the lung. J. appl. Physiol., 21, 749.

Naeye, R. L. (1961). Kyphoscoliosis and cor pulmonale Amer. J. Path., 38, 561.

Prime, F. J. (1965). Routine lung function studies in kypho scoliosis. In Proc. Symp. Scoliosis (London 5-6 July 1965), pp. 57-60. National Fund for Research into Poliomyelitis and other Crippling Diseases, Vincenfo House, Vincent Square, London.

Reid, L. (1969). Pathological changes in the lungs in scoliosis $\omega$ In Scoliosis, edited by P. A. Zorab, p. 67. Heinemank Medical Books, London.

Shannon, D. C., Riseborough, E. J., Valenca, L. M., and Kazemi, H. (1970). The distribution of abnormal lung function in kyphoscoliosis. J Bone Jt Surg., 52, A, 131.

Shaw, D. B., and Read, J. (1960). Hypoxia and thoraci $\bar{\Phi}$ scoliosis. Brit. med. J., 2, 1486.

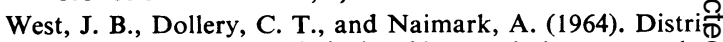
bution of blood flow in isolated lung: relation to vascula and alveolar pressure. J. appl. Physiol., 19, 713. 